\title{
KÉNYSZERŰ HAJLÉKTALANSÁG
}

https://doi.org/10.18030/socio.hu.2021.4.196

\section{BEVEZETÉS ${ }^{1}$}

„1990 és 2000 között a hajléktalanügy civil, majd állami szakmai szervezeteinek vezető beosztásaiban dolgoztam. Ezen belül 1994-től a szakminisztérium módszertani háttérintézményének vezetője voltam, igy munkakörömböl kifolyólag is jelentős szerepem volt a hajléktalan emberek ellátásának megteremtésében és jogi szabályozásának kialakitásában. Ezt a munkámat nagy elkötelezettséggel és komoly személyes befolyással végeztem. Öszintén hittem abban, hogy az igazi megoldást az jelenti, ha átvesszük a nyugat-európai gyakorlatot, és azt adaptáljuk a hazai viszonyokra.

Ez sajnos súlyos tévedés volt a részemröl. Nem számoltam néhány fontos körülménnyel. Az első ezek közül, hogy a nyugat-európai társadalmak évszázados hagyományai álszent gyakorlatot takarnak, amennyiben a megfelelő ellátási kapacitások hiányát és a többnyire korrekt jogi szabályozás be nem tartását a személyes szabadságjogokra való hivatkozással leplezik - vagyis - mentális állapotától gyakorlatilag szinte függetlenül - mindenkinek joga van úgy dönteni, hogy közterületen, a szabad ég alatt éjszakázik. (Minden egyes utcán éjszakázó személy ellátási költség-megtakarítást jelent az államnak, ugyanakkor rá lehet bízni őket az öntevékeny civil és egyházi szervezetek utcára vitt szolgáltatásaira.)

A második fontos körülmény, hogy a mintának tekintett országokban-Magyarországgal szemben - erös intézményrendszere volt mind az idös emberek, mind a pszichiátriai betegek, mind a fogyatékkal élök ellátásának, és a fiatalok drogproblémáinak kezelése is többlépcsős, kiépült rendszerrel rendelkezett. (Hasonlóan, bár nem hézagmentesen, de a szabadságvesztésből szabadulók és az állami nevelésböl nagykorúvá válók ellátásának, támogatásának hálózata is létezett.) Súlyosbitotta a különbségek hatását, hogy a rendszerváltozást követő években idehaza fokozatosan leépitették mind a pszichiátriai, mind a szenvedélybetegek ellátórendszerét, illetve kapacitásait, és a drogprobléma kezelése is folyamatosan, a mai napig tartóan legitimációs és finanszírozási nehézségekkel birkózott.

Az idősellátás is komoly változáson ment át, amennyiben vegyes finanszírozásúvá vált, azaz jelentős összegű belépési dijakhoz, és magas havi téritési dijakhoz kötötték az igénybevételt - vagyis az alacsonyabb nyugdijjal és minimális vagyonnal rendelkezö, illetve vagyontalan emberek néhány éven belül végleg kirekesztődtek az idősotthoni ellátásból. Gyakori - és a mai napig érvényes - jelenség volt az is, hogy az idős emberek lakásfenntartás nehézségei, illetve lakásvesztése vezettek a hajléktalanellátásba.

Ezek a körülmények többek között azzal a következménnyel jártak, hogy a hajléktalan emberek ellátásának intézményi körébe szorultak be, jutottak valamilyen elhelyezéshez a pszichiátriai betegek, a fogyatékkal élök és a szenvedélybetegek mellett az idős emberek, a volt állami gondozottak és a szabadságvesztésből szabadulók is.

1 Köszönettel tartozom a folyóirat szerkesztőségének, hogy helyet adnak „irreguláris”, a folyóirat tudományos hagyományait és talán szabályait is feszegető tanulmányomnak, amellyel publikációs járatlanságom miatt többet kellett bajlódniuk is. 
Ebben a helyzetben kizárólag a hajléktalanellátás részesült fejlesztési pénzekben, azonban fejlesztésként csak a férőhelyszámok fokozatos növelése valósulhatott meg. Szó sem lehetett arról, hogy az intézményekben már bent élö, vagy elhelyezésre szoruló emberek az állapotuknak megfelelö (pszichiátriai, fogyatékkal élö, vagy szenvedélybeteg) ellátáshoz juthassanak - hiszen ezek bövitésére nem volt fedezet.

A munkaerőpiac radikális beszükülését és a lakáspiac bemerevedését, illetve kedvezőtlen viszonyait most csak mint a társadalmi integrációt önmagában is jelentősen nehezítő társadalmi alapot említem. A fentebb felvázolt fejlemények olyan kaotikus körülményeket teremtettek a hajléktalan emberek ellátására létrehozott intézményekben, ami nagyrészt ellehetetlenítette az igazán hatékony szociális munkát.

Az ágazati irányitás ugyanakkor a férőhelybövités kizárólagossága mellett döntött, mert ez egyszerüen és kockázatmentesen eladható volt a politikai vezetés felé, hiszen a férőhelybővités a politika számára is jó kommunikációs eszközt jelentett. A szakterület intézményei, szervezetei pedig örültek a szakterület privilegizált helyzetének, a folyamatosan és kizárólagosan érkező fejlesztési pénzeknek és lehetőségeknek. Igazság szerint intézményvezetőként korábban magam is évekig sodródtam az eseményekkel, amikor pedig felismertem és megfogalmaztam a problémákat, mind a magam, mind a szakterület számára, már késő volt, nem találtam szövetségeseket a szükséges változásokhoz, és néhány év után feladtam.

Egy szó, mint száz, a mai napig felelősnek érzem magam a kialakult állapotokért."

A fenti sorok a Budapesti Módszertani Szociális Központ és Intézményei igazgatói pályázatára 2016-ban készített pályázatom bevezető sorai. Akkor azzal a határozott szándékkal engedtem a felkérésnek, hogy még egyszer megkísértem a lehetetlent. 40 hónapom volt rá. Nem jártam sikerrel.

E tanulmányban áttekintem a társadalmi gondoskodás rendszerváltást követő változásait az úgynevezett tartós bentlakásos és átmeneti elhelyezést nyújtó szociális intézmények (idősek otthonai, fogyatékos személyek otthonai, pszichiátriai betegek otthonai, szenvedélybetegek otthonai, hajléktalanok éjjeli menedékhelyei és átmeneti szállásai) helyzetére vonatkozóan, ezen belül is különös tekintettel a hajléktalan emberek intézményes ellátásának alakulására.

Kiemelt kérdésként foglalkozom azzal, hogy változott-e érdemben az intézményes ellátásra szoruló hajléktalan emberek helyzete az elmúlt évtizedekben, illetve ennek milyen akadályai voltak - ezt jelen tanulmány központi kérdéseként kezelem. Ennek keretében röviden és elsőként itt ismertetem egy közel 6000 - Budapesten, valamint a dél-dunántúli és az észak-alföldi régióban élő - hajléktalan emberre vonatkozó 2018-ban készült felmérés adatait, amely felmérés témánkhoz illeszkedő módon elsősorban az életkorukra, az esetleges pszichiátriai betegségükre, szerhasználatukra-függőségükre, valamint az egészségi állapotukra, önellátási képességükre fókuszált.

Megvizsgálom ezen kívül, mennyire hozzáférhetőek a fenti szociális intézmények a rászorulók számára, és ebben milyen szerepet játszik személyes vagy családi fizetőképességük, milyen következményekkel jár a megfelelő fizetőképesség hiánya. Ezzel összefüggésben érzékelhető-e a hajléktalan emberek, valamint az őket ellátó intézmények körében az esetleges kirekesztődés hatása, és megfelel-e a jogszabályoknak a hajléktalanként történő ellátásuk.

Továbbá a fentiekhez kapcsolódóan röviden áttekintem, hogy a korábbi Alkotmány, illetve a hatályos Alaptörvény nyújt-e garanciát a megfelelő szociális ellátásra, valamint azt, hogy az EU-csatlakozásunkat követő uniós fejlesztési források a hajléktalanellátásban eredményesen kezelték-e a korábban már feltárt jogszabálysértő mértékű infrastrukturális hiányosságokat és működési diszfunkciókat. 
„....Nyeltem is jóslatom, bús agg Jónás, Ninivében.”

A társadalmi gondoskodás a mindenkori emberi társadalmak kulcskérdése, morális állapotának, fejlettségének fokmérője. Mértékének, mibenlétének, változásainak mentén leírható az emberi társadalom fejlődésének története. Az alábbi idézet a Magyar Hírlap 1997. május 31-én „A hajléktalan (is) ember - Beszélgetés Gyuris Tamással" címmel megjelent cikkből származik:

„Milyennek kellene lennie a hajléktalanokat ellátó intézményrendszernek?

Ha valaki erröl vitát akar nyitni, azt tanácsolom, hogy elöször menjen el egy átmeneti szállóra, és akkor ott úgy fogja magát érezni, mint a középkori asylumokban, ahova mindenkit bezsúfoltak, akivel a társadalom nem tudott mihez kezdeni, de azért felakasztani mégsem akarta. Az átmeneti szállókon megtalálható a már-már magatehetetlen, idős, beteg ember, a narkós fiatal, az alkohol-karrierjének teljében lévő középkorú férfi, a súlyosan értelmi fogyatékos, a mozgássérült, a korábban elmebetegnek nyilvánított ember, a TBC-s és az AIDS-es is ugyanúgy. Ha pedig megtörténhet, hogy ezek az emberek tizennyolc és nyolcvanhat év között, ugyanazok között a falak között élnek, akkor nem lehet arról beszélni, hogy van megfelelö intézményrendszer....

... a hajléktalan-társadalmon belül van egy munkaképes réteg. Ennek a rétegnek, akárcsak a betegnek, a mozgássérültnek, a szellemi fogyatékosnak, az idősnek - szintén nem a hajléktalanszálláson volna a helye...

Az átlagember úgy gondol a szociális munkásra, mint adekvát eszközre a probléma megoldásában. De a szociális munka nem adekvát eszköze a szociális probléma megoldásának. Sajnos még a kezelésének sem. Mert megfelelő feltétételek hiján azt sem tudja igazán teljesíteni. Ezzel szemben a társadalom a saját felelősségét a szociális munkásra ruházza át, személyében teszi felelőssé a segítségre szoruló ember életéért, és álszent, háritó módon, tőle vár érdemi megoldásokat egy olyan jelenségre, amelyre nincsenek megfelelö társadalmi válaszai."

\section{AZ ALKOTMÁNY ÉS AZ ALAPTÖRVÉNY MINT PREDESZTINÁCIÓ}

A szociális biztonsághoz való jogosultság alapvető dokumentuma - a legfőbb jogszabály, amelyre minden további szabályozás visszavezethető (kell legyen) - a mindenkori Alkotmány, vagyis ennek változásai, meghatározásai döntő fontosságúak a témánk szempontjából - ez a körülmény indokolja, hogy kiemelt figyelmet fordítsunk rá.

Az 1989. évi XXXI. tv. 70/E. §-a szerint

„(1) A Magyar Köztársaság állampolgárainak joguk van a szociális biztonsághoz; öregség, betegség, rokkantság, özvegység, árvaság és önhibájukon kíü̈l bekövetkezett munkanélküliség esetén a megélhetésükhöz szükséges ellátásra jogosultak.

(2) A Magyar Köztársaság az ellátáshoz való jogot a társadalombiztositás útján és a szociális intézmények rendszerével valósítja meg."

Az Alkotmány idézett paragrafusának az értelmezése nem volt egységes az Alkotmánybíróság tagjai között sem. Kulcsfontosságú kérdés volt, hogy a fentiek alanyi jogot vagy csupán állami feladatot jelentenek. Végül olyan határozat született, mely szerint az állam feladata az, hogy az ország teherbíró képességének függvényében szociális kihatású normákat alkosson, azonban ezen kötelezettségei nem jelentenek alanyi jogot egy bizonyos meghatározott jövedelem megszerzéséhez vagy életszínvonal fenntartásához. 
Megállapíthatjuk tehát, hogy az állampolgárok szociális biztonságra való számonkérhető, tényleges, garanciálisan érvényesíthető jogosultsága már a kezdeteknél elbukott. Igazság szerint ugyanakkor, egyrészt ez a fajta szabályozás volt a leggyakoribb Európában, másrészt ez felelt meg az akkori gazdasági realitásoknak is.

1998-at követően „az Alkotmánybíróság rögzítette a szociális biztonság alapjogi tartalmát: az Alkotmány 70/E. §-ában meghatározott szociális biztonsághoz való jog a szociális ellátások összessége által nyújtandó olyan megélhetési minimum állami biztosítását tartalmazza, amely elengedhetetlen az emberi méltósághoz való jog megvalósulásához" [42/2000. (XI. 8.) AB határozat, 200/329]. Az Alkotmány alapján tehát az állampolgárok jogosultak voltak a megélhetési minimumot garantáló ellátásra. Ez az alapjog 2000-ben kiegészült a hajlékhoz való joggal, abban az esetben, ha az emberi életet közvetlenül fenyegető veszélyhelyzet elhárításához szükséges a szállás [42/2000. (XI.8.) AB határozat]. E minimumok fölötti szolgáltatások biztosítása olyan - alapjognak nem minősülő - alkotmányos jog volt, amelyre vonatkozóan az államra csak a társadalombiztosítás és a szociális intézmények létrehozásának és múködőképes fenntartásának feladata hárult (Kiss 2016).

Az új Alaptörvény 2012-ben alapvető változásokat hozott a szociális biztonság szabályait illetően. A XIX. cikk szerint

„(1) Magyarország arra törekszik, hogy minden állampolgárának szociális biztonságot nyújtson. Anyaság, betegség, rokkantság, fogyatékosság, özvegység, árvaság és önhibáján kívül bekövetkezett munkanélküliség esetén minden magyar állampolgár törvényben meghatározott támogatásra jogosult.

(2) Magyarország a szociális biztonságot az (1) bekezdés szerinti és más rászorulók esetében a szociális intézmények és intézkedések rendszerével valósítja meg.

(3) Törvény a szociális intézkedések jellegét és mértékét a szociális intézkedést igénybe vevő személynek a közösség számára hasznos tevékenységéhez igazodóan is megállapithatja.

(4) Magyarország az időskori megélhetés biztositását a társadalmi szolidaritáson alapuló egységes állami nyugdijrendszer fenntartásával és önkéntesen létrehozott társadalmi intézmények müködésének lehetővé tételével segíti elö. Törvény az állami nyugdíjra való jogosultság feltételeit a nök fokozott védelmének követelményére tekintettel is megállapithatja."

Az újraszabályozás elvi alapjai kapcsán a 23/2013. (IX.25.) AB határozat egyfajta „szociálpolitikai paradigmaváltásról” beszél. Az alkotmányozók a fenntartható gazdasági fejlődésre és a romló demográfiai helyzetre hivatkozva a valós lehetőségekhez igazították az Alaptörvény szövegét (Kiss 2016). A változás két alappillére a szociális biztonság államcéllá szükitése („törekszik” kifejezés) és az öngondoskodás filozófiájának érvényesítése, vagyis a feltételekhez köthető ellátás bevezetése volt. Az állam kötelezettsége továbbá a „megélhetéshez szükséges” ellátási szintből a „törvényben meghatározott támogatási” szintre változott.

Megállapíthatjuk tehát, hogy a szociális biztonsághoz való jognak államcéllá „szelídítése”, a megélhetési minimum garantálásának feladása azzal a veszéllyel jár, hogy az Alkotmánybíróság a szociális ellátások területén a jogok egyre megszorítóbb értelmezése irányába mozdul el (Kiss 2016). Az Alkotmánybíróság szerint az Alaptörvény a szociális biztonsághoz való alkotmányos alanyi jogot nem tartalmaz, az Alaptörvény XIX. cikkében szereplő „törekszik” kifejezés azt deklarálja, hogy Magyarországon a szociális biztonság garantálása nem alanyi alapjog, hanem csak államcél. Az Alkotmánybíróság szerint ez az Alaptörvény N. cikkével (a kiegyensúlyozott, átlátható és fenntartható költségvetési gazdálkodás elve) együttesen ez az államcél azt a kötelezettséget rója az Országgyúlésre és a Kormányra, hogy az ország gazdasági állapotát, teljesítóképességét figyelembe véve határozzák meg az állami szociálpolitikának azon alapelemeit, melyek garantálása állami feladat. Ez mindössze a 
szociális ellátórendszer fenntartását és múködtetését követeli meg az államtól, anélkül azonban, hogy bármely ellátás konkrét formájára és mértékére vonatkozóan bárki számára Alaptörvényben biztosított jogot keletkeztetne - ahogyan ezt Rácz Zoltán is kifejtette (Rácz 2016).

Az Alkotmány és az Alaptörvény változásainak áttekintésekor azt láthatjuk tehát, hogy az 1989-ben még érthetően óvatos és „szǔkmarkú” meghatározások a gazdasági helyzet konszolidálódásával, javulásával nemhogy „gondoskodóbb” irányba változtak volna, hanem éppen ellenkezőleg. Az Alaptörvény a szociális biztonság szempontjából immár semmilyen garanciát nem jelentő, sőt, a kirekesztő társadalmi gyakorlatot megalapozó dokumentummá vált. Ezen a ponton tehát akár abba is hagyhatnánk jelen tanulmány írását, hiszen kis túlzással kijelenthető, hogy bármelyikünk szociális biztonsága esetleges, bármelyikünkkel bármi jogszerűen megtörténhet. Végső soron megállapíthatjuk, hogy az Alaptörvény amennyire a szabályozás forrását, legalább annyira a probléma forrását is jelenti.

\section{SÜNDISZNÓÁLLÁSBAN - AVAGY A TARTÓS BENTLAKÁSOS ÉS AZ ÁTMENETI ELHELYEZÉST NYÚJTÓ INTÉZMÉNYEKRŐL}

Átlag feletti jövedelem és/vagy család nélkül nincs esély

Az ellátottak számát tekintve azt látjuk, hogy 1993 és 2019 között legnagyobb mértékben az időskorúak férőhelyszáma növekedett, összesen 25345 férőhellyel, ami 84\%-os növekedést jelent (KSH 2019). Legnagyobb arányban a hajléktalan emberek ellátását szolgáló férőhelyek növekedtek, 273\%-kal, ami összesen 6198 férőhelynövekményt jelent.

A többi intézménytípusban csekély volt a változás - a pszichiátriai betegek otthonaiban mindössze 235 férőhely, a fogyatékosok otthonaiban 1799 férőhely és a szenvedélybetegek otthonaiban összesen csupán 1210 férőhely volt a növekmény 28 év alatt - és mint látni fogjuk, ez a csekély növekedés is csak 2010-ig tartott (KSH 2019:160-161, 9.5. táblázat). Az idősotthonok kapacitásainak növekedése mögött természetesen a demográfiai folyamatok állnak, hiszen a rendszerváltás óta a 65 éves és ennél idősebb népesség aránya 13\%-ról 19\%-ra növekedett.

A térítési dijjak összege döntő körülmény a hozzáférhetőség, a férőhelyek igénybevételének szempontjából. A korábbi szakmai államtitkár és a szakmai minisztérium volt főosztályvezetőjének tanulmánya erről a következőképpen nyilatkozik: „Magyarországon a szociális szolgáltatások jogosultságának szabályozása szinte minden esetben az univerzalitás elvére épül, és ez az alapvető megközelítés nem változott az elmúlt húsz évben sem. Ez azt jelenti, hogy a szociális szolgáltatások igénybevételének nem feltétele az alacsony jövedelem, a szegénységi kockázat. Amennyiben a szabályozás elő is írja az igénybe vevő jövedelmének vizsgálatát, ezt nem azzal a céllal teszi, hogy a szolgáltatás igénybevételét ezzel megalapozza, hanem általában a szolgáltatás igénybevételéért fizetendő téritési dij kiszámítása érdekében" [kiemelés tőlem] (Czibere-Mester 2020:439).

Sajnálatos módon ezzel szemben mégis azt látjuk, hogy az alacsony jövedelem önmagában is kirekesztő körülmény. A bentlakásos intézmények térítési díjainak alakulása azt mutatja, hogy miközben az intézmények múködési költsége tizenötszörösére emelkedett 26 év alatt, addig a befolyt térítési díjak összege közel kétszer akkora arányban - huszonyolcszorosára - emelkedett, vagyis az ellátási költségeket egyre nagyobb mértékben terhelte az állam és a fenntartó az ellátottakra, illetve a családjukra. Ez alapvetően két költségelemből áll, a személyi térítési díjból, amelyet havonta ténylegesen fizetni kell az ellátottak után, valamint az egyszeri belépési díjból, amely jellemzően a komfortosabb elhelyezés feltétele. 
A KSH az utóbbit nem tartja nyilván, de a térítési díjakról kötelezően adatot kell szolgáltatnia az intézményeknek. Ezek az adatok azonban a Szociális Statisztikai Évkönyvekben csak ömlesztve, az összes intézményre vetítve jelennek meg, fenntartók szerint, de számos más adattal szemben ezt nem adják meg ellátási típusonként, az ömlesztett adatok pedig sajnos nem alkalmasak megbízható számításra. Ez az oka annak, hogy ezt a fontos kérdést nem tudjuk hagyományos, egyszerű adatelemzéssel bemutatni.

Az internetes tájékozódás alapján az tapasztalható, hogy ezek az összegek többnyire egyik esetben sem transzparensek, illetve garantáltan kizárólag az önkormányzati/központi költségvetési intézmények esetében ismeretesek. A személyi térítési díj esetében ez magyarázható azzal, hogy csak az intézményi térítési díj konstans intézményenként, a személyi térítési díjat ebből kell számolni minden esetben, utóbbi tehát ellátottanként eltérő. Fontos körülmény, hogy az ellátott nyugdíjának 80\%-ánál nem lehet magasabb ez az összeg, de a többletfizetést a család önként vállalhatja. Ezzel együtt is - 2021 első hónapjaiban is- számos más fenntartású intézmény fix személyi térítési dijjat közöl a honlapján, amelynek összege havi 200-250000 forintnál kezdődik. A fővárosi önkormányzati intézményekben az átlagos összeg 2019-ben mintegy 170000 forint (Szalai 2019). Ekkora személyi térítési díj 204000 forintos nyugdíj esetén állapítható meg a szabályok értelmében. Tekintettel arra, hogy a nyugdíjasok 82,77\%\%-ának a nyugdíja 200000 forint alatti összeg 2021. januárjában a KSH adatai szerint (KSH STADAT 2021), a család fizetőképessége kulcskérdés lehet.

Az évi átlagnyugdíj 142114 forintos összegéből (KSH STADAT 2019) következik, hogy szabályszerűen 112.000 forintos személyi térítési díj állapítható meg az átlagnyugdíjasnak, vagyis a családnak havonta további 60.000 forintot kell fizetnie az idősotthoni ellátásáért még egy önkormányzati intézményben is.

Hozzá kell tennünk ugyanakkor, hogy minden szektorban ehhez képest emelt díja van a rosszabb egészségi állapotú, illetve demens idősek ellátásának.

Két körülmény enyhíthet a helyzeten. Egyrészt az átlagosnál értelemszerűen alacsonyabb térítési dijjú intézmények, férőhelyek is vannak, másrészt az önkormányzati intézményekben kérelmezni lehet a díj csökkentését, illetve elengedését is. Hasonló a helyzet a pszichiátriai és a fogyatékos emberek otthonai esetében is.

Az egyszeri belépési díjat illetően - ahol egyáltalán elérhető bármi információ - nagyok a különbségek, az önkormányzati intézmények mintegy 500 ezer és 6 millió közötti összegével szemben a piaci alapon múködő intézmények esetében ennél is több - a Szociális Törvény 117/C.§. (2) bek. 8 millió forintban maximálta ezt az összeget - jellemzően a komfortfokozattól és a jelentkező életkorától, egészségi állapotától függően. A belépési díj tulajdonjoggal nem jár, csupán bérleti jogot jelent. A tisztán piaci alapon, azaz nem szociális intézményként, hanem vállalkozásként, állami támogatás igénybevétele nélkül múködő nyugdíjasházaknál nincs felső korlát, a hírek szerint akár 20 millió forint is lehet a belépési díj (Szalai 2019).

Az idősotthoni felvételek esetében azonban nem csupán az anyagi feltételek jelentenek leküzdhetetlen akadályt, hanem gyakorlatilag kizáró ok a pszichiátriai probléma és a szenvedélybetegség. Ez azt jelenti, hogy a rászoruló idős embereket tömegesen szorítja a rendszer a gyakorlatilag 28 éve változatlanul elégtelen kapacitású, szabad férőhelyek nélküli pszichiátriai intézmények felé, és így számukra kizárólag a hajléktalanellátás vagy az utca marad. 
Kapacitásszabályozás - valójában felvételi zárlat, avagy leépítés

Az idősellátás esetében már láttuk, hogy az alacsony jövedelmű, a családi kapcsolatok nélküli, a rossz mentális állapotú, a pszichiátriai problémákat mutató vagy a szenvedélybeteg idős emberek számára szinte lehetetlen az idősotthonba bejutni. Ennek megfelelően a következőkben a pszichiátriai betegek, a fogyatékossággal élők és a szenvedélybeteg emberek intézményes ellátásának esélyeire fókuszálunk, ami annál is inkább releváns szempont, mivel 2012-ben az állam ezeket az intézményeket elvette az önkormányzatoktól, és kiváltva adósságukat, állami fenntartásba vonta őket.

A tartós bentlakásos intézményekben az 1993 és 2019 közötti időszakban mintegy 63-64\%-kal emelkedett a férőhelyek száma és az ellátottak száma (KSH 2019). Ez a növekedés azonban csupán az 1993 és 2010 közötti időszakra igaz, azt követően az idősotthonok kivételével nagyon más képet látunk.

A pszichiátriai betegek, a fogyatékossággal élők és a szenvedélybetegek ellátásának kapacitásai 2010 és 2019 között 338 férőhellyel csökkentek (KSH 2019:160-161. 9.5. táblázat). Az átmeneti elhelyezést nyújtó intézmények férőhelyeinek és ellátottjai számának növekedése 1993 és 2019 között (KSH 2019:157. 9.2. táblázat) ugyan jelentősebb mértékű, több, mint 100\%-os, azonban ez alapvetően a hajléktalanellátás intézményrendszerének kiépülésével magyarázható, és a növekedés itt is lassul 2009 táján (KSH 2019).

2010 és 2019 között az idősek átmeneti elhelyezésének kapacitásai több mint 20\%-kal csökkentek, a szenvedélybetegek férőhelyei 30\%-kal csökkentek, a fogyatékossággal élőké stagnáltak, a pszichiátriai betegek átmeneti férőhelyei 88-ról 101 férőhelyre „növekedtek”. A férőhelybővülési folyamat megrekedése alapvetően az állami beavatkozás eredménye.

Az engedélyezett férőhelyek száma 2015 óta egyetlen százalékkal emelkedett, az ellátottak száma pedig gyakorlatilag változatlan. Mivel az új rendszer döntési mechanizmusa, a befogadás feltételrendszere nem tisztázott, így maga a befogadási döntés folyamata sem transzparens. Az ellátás iránti tömeges és kielégítetlen igények ismeretében egy dolog biztos: a döntések ma sem az igények és a szükségletek mérésén, vizsgálatán alapulnak.

Tekintettel arra, hogy az elhelyezés iránti igények minden ellátási típusban és mindenkor meghaladták az elhelyezési lehetőségeket, az informális várólisták egyidősek az intézményekkel. A várólisták utóbb hivatalossá váltak, amikor 2015-ben a Szociális Törvénybe bekerült az a (20§/a) passzus, amely szerint az intézményeknek havonta jelenteniük kell az Államkincstár felé a „nyilvántartásban lévő kérelmezők” adatait. 2016 júniusától ezeket az adatokat havonta nyilvánosságra hozták. Az intézmények adatközlési kötelezettsége ma is él, azonban 2019 decembere óta ezek az adatok már nem nyilvánosak - a „jogszabály erejénél fogva”, ahogyan az Államkincstár illetékese tájékoztatott.

Az alábbiakban tehát az említett - vagyis a 2016 június és 2019 december közötti - időszak adatait ismertetem. 2016 júniusában legtöbben az idősotthoni férőhelyre várakoztak, összesen 16853-an. ${ }^{2}$

A hajléktalanok otthonába történő elhelyezésre 775 ember várakozott, vagyis a várakozók száma meghaladta a férőhelyek számát. Ugyanez a helyzet a pszichiátriai betegek átmeneti elhelyezésére várakozók esetében is. 1846 személy várakozott pszichiátriai otthoni férőhelyre, 1407-en pedig a fogyatékosok otthonára. Az idősotthonoknak 2016-ban csak háromnegyede, és 2019-ben is csak 79\%-a szolgáltatott adatot, a pszichiátriai betegek otthonainak 88\%-a, míg a fogyatékos személyek otthonainak 80\%-a.

2 Ez az adat a ténylegesen várakozó személyek adata, a többes jelentkezések TAJ-szám alapján történő kiszűrésével. 
Az adatokat tovább súlyosbítja, hogy Skultéty József, a legnagyobb magyarországi idősotthon (és a Főpolgármesteri Hivatal korábbi szociálpolitikai főosztályvezetője) akkori igazgatójának 2019-es tájékoztatása szerint a valóságos igény még a regisztráltnál is nagyobb lehetett, mert a leghosszabb várólistával rendelkező helyeken már nem is regisztrálják az újabb kérvényezőket (Szalai 2019). 2019 decemberében tehát már közel kétszerannyian vártak idősotthoni elhelyezésre, mint három és fél évvel korábban. A pszichiátriai betegek otthonára 44\%-kal, fogyatékossággal élők elhelyezésére 48\%-kal és szenvedélybetegekére 66\%-kal többen várakoztak, mint három és fél évvel korábban.

A hajléktalanok otthonára várakozók száma ugyan 12\%-kal csökkent, azonban így is közel annyi a várakozó, mint az összes férőhely (Várakozók Jelentése 2016, 2019). Ennek a csökkenésnek több oka is van ugyanakkor. Egyrészt a hajléktalan emberek mögött nem áll egy az elhelyezésükben érdekelt, motivált család, akik menedzselnék ezt a folyamatot, másrészt tapasztalataim szerint a szociális munkások nagy része azzal sincs tisztában, hogy létezik ez az intézménytípus, valamint az önkormányzatok túlnyomó többsége nem tart fenn ilyen intézményt, tehát nincs is hova jelentkezni.

A fenti adatok egyértelmúen azt mutatják, hogy hatalmas az igény a tartós bentlakásos intézmények iránt, összesen közel 38000 ember - a nyilvántartásban nem szereplő fővárosi intézmények adatait is számolva pedig 44000 ember volt várólistán másfél évvel ezelőtt. Ezt az adatot azonban úgy kell értelmeznünk, hogy ennyi a fizetőképes jelentkező.

Azok pedig, akik (vagy a családjuk) nem képesek kifizetni a térítési díjakat, fel sem kerülhettek a várólistára, ugyanis oda már eleve csak olyan személyek kerülhetnek fel, akik megfelelnek az állapotukra, körülményeikre, fizetőképességükre vonatkozó előzetes feltételeknek. Ezeket a feltételeket pedig a Szociális Törvény folyamatos szigorításai miatt egyre nehezebb teljesíteni.

A hajléktalan emberek között rengeteg a lakását-lakhatását vesztő, jellemzően rossz mentális állapotú, esetleg dementálódó idősebb ember. A kilencvenes években egy ideig az volt a szakmai közmegegyezés, hogy súlyos hiba, hátrányos megkülönböztetés lenne az „ellátás megkettőzése”, vagyis a pszichiátriai beteg vagy fogyatékossággal élő, esetleg szenvedélybeteg hajléktalan emberek számára külön intézményeket létrehozni, hiszen adottak a rendszerben azok az intézmények, amelyekben ezek a problémák kezelhetőek. Néhány év alatt azonban nyilvánvalóvá vált, hogy ez csupán elméleti lehetőség, valójában ezek az intézmények a lakhatásukat elvesztő emberek számára szinte elérhetetlenek. Kisebb csoda folytán, de 1999-ben sikerült a Hajléktalanok rehabilitációs intézménye és a Hajléktalanok otthona elnevezésű intézményeket jogszabályba foglalni, és az utóbbiban úgynevezett speciális részlegek kialakitására is lehetőség van, illetve lenne a pszichiátriai betegek vagy a fogyatékossággal élők számára is.

Hajléktalanok otthona azonban minimális számban jött csak létre - Budapesten egyetlen intézmény található, 66 férőhellyel -, alapvetően a költséges kialakítás, valamint az állami támogatást magasan meghaladó fenntartási költségek miatt. Az „elsődleges” intézményekbe való bejutás fent bemutatott lehetetlenségei dacára, a mai napig ez a fő hivatkozási alap a szakterületi változásokat ellenzők körében. 


\section{VÁLTOZÁSOK AZ INTÉZMÉNYFENNTARTÓI VISZONYOKBAN}

„Az intézményes szolgáltatások közül föleg az idősotthonok férőhelyeinek száma növekedett a 2000-es évek elején, döntően a Széchenyi Terv támogatásainak köszönhetően. A 2000-es évek végétöl azonban a látványos kapacitásnövekedés leállt: részben azért, mert az állam csökkentette az új, magas színvonalú férőhelyek támogatását, részben azért, mert az Európai Unió támogatási logikája a nappali ellátások fejlesztését preferálta a bentlakásos intézményekével szemben" - írta Czibere Károly és Mester Dániel (2020:443). A férőhelyek bővítése valóban megtorpant, de egyéb változások mondhatni fel is gyorsultak, mégpedig az intézmények fenntartói viszonyait illetően.

Ez a folyamat tulajdonképpen 1997-ben indult, amikor a kormány a Vatikáni Szerződés keretében vállalta, hogy a katolikus egyház számára is biztosítja azt a plusz támogatást, amelyet az állami normatíván felül korábban csak az önkormányzati szociális és oktatási intézmények kaptak meg. Ezt követően a többi egyház is hasonló módon részesült ebben a plusz támogatásban. Így született meg az egyházi normatíva, amely később „önálló életre kelt”, és elszakadva az azonos feladatot ellátó önkormányzati és központi költségvetési intézmények támogatásától, az elmúlt 10-15 évben jelentősen megváltoztatta az intézmények finanszírozásának erőviszonyait, az egyházi intézmények, illetve fenntartók javára.

A számok nyelvén szólva ez annyit jelent, hogy ugyan a korábbi években kissé nagyobb volatilitással változott, azonban 2014 óta 70-80\% között mozog a plusz támogatás mértéke (Gyarmati 2019). A változások másik gyökere a szociális és gyermekvédelmi intézmények egy részének úgynevezett államosítása, amikor is az állam 2012-ben a pszichiátriai betegek, a fogyatékossággal élők és a szenvedélybetegek intézményeit elvéve az önkormányzatoktól saját fenntartásába vonta. Ekkortájt született az a nem nyilvános politikai döntés, hogy a szociális intézmények fenntartását át kell adni az egyházaknak, amely döntés csak ráerősített arra a már megkezdődött folyamatra, hogy egyre több civil, de önkormányzati intézmény is saját elhatározásából az egyházi normatíva védőszárnyai alá menekült, a személyes egzisztenciák megőrzése és az intézmény pénzügyi stabilitása érdekében.

Az informális egyeztetéseket az intézmények átvételéről a szakminisztérium folytatta az egyházakkal, azzal a törekvéssel, hogy csomagban adják át azokat - azaz az egyházak által kiválasztott, jó állapotú és jó helyzetű intézmények mellett, a problémásabb intézményekből is vegyenek át. Ez a törekvés nem mindig volt eredményes, így egyet nem értés esetén előfordult, hogy az egyházak javára szóló döntés végül másutt született meg - legalábbis erre lehetett következtetni minisztériumi vezetőkkel folytatott háttérbeszélgetéseim alapján.

E folyamat végül is (vagy egyelőre) megakadt, lévén, hogy a kormány alábbi, több mint négy évvel ezelőtti, ma is hatályos határozata azóta sem látszik teljesülni. A Kormányhatározat tartalma mindenesetre arra a szándékra utal, hogy az állami fenntartásban múködő tartós bentlakásos intézmények teljes köre az egyházak fenntartásába kerüljön:

„A Kormány 1046/2017. (II. 3.) Korm. határozata

A Magyar Közlöny 2017. évi 16. számában (II. 03.) megjelent a Kormány 1046/2017. (II. 3.) Korm. határozata az egyes állami fenntartásban lévő szociális intézmények egyházak részére történő átadásával kapcsolatos források biztositásáról.

A kormányhatározat alapján az egyházi fenntartók által átvett szociális intézmények biztonságos müködése érdekében a Kormány felhivja a nemzetgazdasági minisztert, hogy az állami fenntartóval az átadás- 
átvételröl 2017. évben megállapodást kötött egyházi fenntartók által átvett 8837 féröhely müködtetéséhez szükséges többletforrást biztositsa; 2017. január 1-jétól a felmerülés ütemében.

A Kormány egyben felhívja a nemzetgazdasági minisztert, hogy a 2018. évben az állami fenntartóval az átadás-átvételről megállapodást kötött egyházi fenntartók által átvett további 21563 férőhely müködtetéséhez szükséges többletforrást biztositsa [kiemelések tölem]". - Információim szerint a nagy egyházak kezdeményezték a folyamat leállitását, részben a kisegyházak térnyerését akadályozandó, részint mert a még megmaradt intézmények átvétele állapotuk és helyzetük miatt már egyre több gondot és kockázatot jelentett volna.

A 2019-es állapotot tekintve, az állami fenntartású intézményben az ellátottak száma átlagosan 376 fő, míg az egyházi intézményekben átlagosan 83 főt látnak el (KSH 2019:157-158. 9.2. és 9.3. táblázat). Az, hogy eddig hány intézményt, illetve hány ellátottat vettek át az egyházak, illetve az egyházközeli szervezetek, a KSH nyilvános adataiból nem állapítható meg pontosan. Ennek oka elsősorban az, hogy nem feltétlenül egyházi, hanem egyéb, nonprofit szervezeti formában múködtetik ezeket az intézményeket, így a változások a statisztikák alapján gyakorlatilag követhetetlenek.

Néhány dolgot még fontos a fentiekkel kapcsolatosan tisztázni. Az úgynevezett államositás nem feltétlenül lett volna rossz döntés ebben az esetben, hiszen azzal az előnnyel is járhatott volna, hogy az ellátás a szükségleteknek megfelelően tervezhetőbbé, alakíthatóbbá válik, továbbá egyszerűbben mérhető lehetett volna az ellátás hatékonysága is, végső soron magasabb színvonalú ellátást lehetett volna biztosítani. Témánk szempontjából kulcskérdés, hogy az „államosítás” ily módon megakaszthatta volna azokat az ellátási szempontból súlyosan kedvezőtlen tendenciákat is, amelyeket az eddigiekben bemutattunk.

A fenti szempontok ugyanis megjelentek anno az érvelésben, azonban a gyakorlatban egy pillanatra sem merültek fel. Az egyházi intézmények térnyerése szintén - tréfásan, de komolyan szólva - nem az ördögtől való, hiszen a több pénzből elvileg színvonalasabb ellátás biztosítható, és a gazdálkodás, a múködtetés stabilitását tovább erősíti az egyházak társadalmi beágyazottsága és a jelenlegi fokozottabb politikai befolyása, érdekérvényesítő képessége. Az egyházi intézményekbe történő felvételt mindenesetre megnehezíti, hogy az itt fizetendő térítési dijak mintegy 10\%-kal magasabbak, mint az átlag.

Végül pedig arra sincsen semmi okunk, hogy kételkedjünk az ott folyó szociális, ápoló-gondozó munka színvonalában. A szakképzett gondozók aránya, és az egy gondozóra jutó ellátottak aránya a más fenntartókkal való összehasonlításban a jobbak közé tartozik (KSH 2019:159. 9.4. táblázat).

Ezzel együtt tény, hogy a változások eredményeként, állami fenntartásban maradtak a kedvezőtlenebb adottságú, rosszabb állapotú intézmények, amelyek ráadásul alacsonyabb összegú támogatásban is részesülnek, amely körülmények az itt élő emberek ellátásának színvonalát is döntően befolyásolják. 


\section{HIÁBAVALÓ FÁRADOZÁSOK}

A Nemzeti Család- és Szociálpolitikai Intézet 2000 szeptemberében történt megalakulásával létrejött a szakminisztérium háttérintézménye, amelynek a szakmafejlesztés és a döntéstámogatás kiemelt feladata volt. Ennek keretében - új megbízatásomként - a Szociálpolitikai Főosztály felállítása és az Elemző Csoport megalakítása is megtörtént. Utóbbi saját hatáskörben, már kifejezetten annak érdekében, hogy felmérjük a hazai szociális intézményrendszer és szolgáltatások állapotát, megalapozandó az Európai Unióhoz történő csatlakozást követő fejlesztéseket és tervezésüket. Jóllehet ilyen megrendelést nem kaptunk a szakminisztériumtól, de az erre irányuló terveinket jóváhagyták. Három év alatt végeztük el ezt a munkát, az egyes szakterületekre vonatkozó, leíró jellegű kutatási jelentéseket az Intézet Kapocs című folyóiratában folyamatosan közzétettük. A munka befejezését követően A szociális szolgáltatások helyzete Magyarországon 2001-2005 címmel egy 600 oldalas kötetben közzé is tettük az Intézet kiadásában. Jóllehet sem azelőtt, sem azóta ilyen teljes körú kiadvány nem készült, a kötet visszhang nélkül maradt, és semmi jele nem volt annak sem, hogy tervezési dokumentumként felhasználták volna.

Az említett kötetben közzétett felmérés keretében tételesen, egyenként vizsgáltuk az intézményi feltételeket az infrastruktúrára, a szolgáltatásokra és a szakalkalmazottak arányára vonatkozóan, hogy az ország intézményei milyen mértékben felelnek meg a múködési feltételeiket meghatározó jogi szabályozásnak (Gyuris et al. 2005).Összességében megállapítottuk, hogy a 79 átmeneti szállásnak csupán 13,9\%-a volt minden szempontból megfelelő, a 43 éjjeli menedékhely közül pedig egyetlen egyet sem találtunk, ami megfelelt volna a hatályos jogszabályi előírásoknak.

A szakminisztérium az uniós csatlakozásra való felkészülés jegyében a tervezést megalapozó kutatási pályázatot hirdetett. A pályázaton nyertes - de a tervezésben figyelmen kívül hagyott - és a hajléktalan emberek ellátásával foglalkozó kutatási jelentésünkből idézek:

„A lakókról vezetett nyilvántartás tanúsága, illetve az intézményvezetők megitélése szerint a lakók (szálláshasználók) 20\%-ának esetében a hajléktalanok otthona, 17\%-ának hajléktalanok rehabilitációs intézménye, 11\%-ának egészségügyi intézmény, 5\%-ának pedig az értelmileg akadályozott, vagy testi fogyatékkal élők intézménye volna az állapotuknak megfelelö elhelyezés. Mindez azt is jelenti, hogy a jelenlegi lakók, illetve a szálláshasználók összesen 53\%-a számára jelenlegi elhelyezésük kényszerü és indokolatlan, amely nem biztosíthatja számukra az állapotuknak és szükségleteiknek megfelelö, szakszerü ellátást.

Megvizsgáltuk a lakók, illetve a szálláshasználók munkaerőpiaci helyzetét is, és azt állapítottuk meg, hogy a szálláshasználók 21 \%-ának állandó munkaviszonya van, 26\% pedig rendszeresen végez alkalmi munkát, melyböl rendszeres jövedelemmel rendelkezik.

Mindez röviden oly módon összegezhetö, hogy az átmeneti szállásokon élök és az éjjeli menedékhelyek szálláshasználóinak mintegy fele az életkora vagy egészségi állapota miatt nem munkaképes, ugyanakkor másik fele állandóan vagy rendszeresen dolgozik.

Az intézményben élök két nagyobb csoportjáról elmondható, hogy - a szúk intézményi, illetve támogatási kapacitásokkal összefüggö, de - diszfunkcionális a szálláshasználatuk. Az egyik csoportnak tartós bentlakásos intézményben, a másik csoportnak - kellö támogatással - a lakáspiacon lenne a helye" (Gyuris 2002). - Hasonló megállapításra jutottunk az intézményrendszer országos vizsgálata kapcsán is (Gyuris et al. 2005). 
Egyértelműen kijelenthető tehát, hogy az uniós tervezést megelőzően rendelkezésre álltak a legfontosabb hiányosságokra és múködési diszfunkciókra vonatkozó információk és adatok. Három uniós pénzügyi ciklussal később mégis azt látjuk, hogy a mai helyzet kísértetiesen hasonló a 20 évvel ezelőttihez - és a még korábbiakhoz.

Egy 2018-as 14000 hajléktalan embert bevonó felmérés alapján megállapítható, hogy ápoló-gondozó intézményben lenne a helye 700 embernek (5\%), mentális-szociális ellátást nyújtó intézetben 2300 főnek (16\%) lakhatási támogatással önállóan megélne 4000 ember (29\%) és lakhatási-mentális-szociális együttes támogatásra 7000 embernek (50\%) van szüksége. Vagyis a jelenlegi hajléktalanellátás mellett megfelelő lakhatási támogatásra, helyi mentális és szociális segítő hálózatra, az alkohol-, drogfüggőknek, pszichiátriai betegeknek rehabilitációs szolgáltatásokra, az értelmileg akadályozott, vagy testi fogyatékkal élő embereknek támogató szolgáltatásokra, a krízishelyzetbe kerülteknek kríziskezelő központokra lenne szükségük. A megkérdezettek 43\%-ának súlyos betegsége van, és 49\%-nak nehézséget okozna, ha segítség nélkül kellene élnie (Február Harmadika Munkacsoport 2018).

Az ellátatlanság struktúrája tehát gyakorlatilag nem változott, egyedül a munkaképes, munkajövedelemmel rendelkezők száma csökkent radikálisan, amit elsősorban a hajléktalanok mai, jelentősen magasabb átlagéletkora és rosszabb egészségi állapota magyaráz.

Nem volt ismeretlen a probléma a szakminisztérium számára már 2011-ben sem. Az Állampolgári Jogok Biztosának jelentése a miniszter válaszából a következőképpen idéz:

„Megemlitette továbbá azt a sajnálatos gyakorlati tapasztalatot, hogy például idősek otthonában igen korlátozott számban és meglehetösen nehezen lehet hajléktalan embereket elhelyezni, noha a jogszabályi feltételek alapján az elhelyezés nem okozhatna gondot. A miniszter válaszában azzal együtt, hogy a fejlesztésekre jelen költségvetési körülmények között igen kevés esély mutatkozik, elismerte azt a problémát, hogy a hajléktalan ápoló-gondozó otthonok féröhelyszáma is rendkivül alacsony" (AJB-3240/2011).

A fenti megállapításoknál meg kell álljunk. Mit is jelent ez valójában? Amennyiben a hajléktalan emberek egyik fele egy, az állapotának megfelelő, és a rendszerben amúgy létező intézményből kiszorul, kirekesztődik és nem jut elhelyezéshez, a másik fele pedig dolgozik, de a jövedelme nem elégséges a lakhatásának a biztosításához, és lakás híján még lakhatási támogatásra sem jogosult, akkor ki is a hajléktalan, és mit is jelent a hajléktalanság valójában?

Olyan emberekről beszélünk, akiktől valamilyen okból megtagadjuk azt a segítséget, amelyet másnak megadunk. Kiszolgáltatott, emberhez méltatlan, akár életét is veszélyeztethető állapotára alkotunk egy elnevezést, egy fogalmat: hajléktalan. Ez nem több egyszerű szómágiánál, amely beteljesíti küldetését, amennyiben eltakarja a lényeget, eltünteti a személyességet, megszokhatóvá, majd természetessé teszi a borzalmat és áthárítja a felelősséget.

\section{Építsünk légvárat!}

A megváltásként várt uniós pályázatok igazi pénzesőt jelentettek a hajléktalanellátás sivár, lepusztult intézményei és szűkös szolgáltatásai számára is. Az első, hároméves támogatási időszakban épült néhány korszerű ingatlan, azonban ezek a beruházások országos szinten nem hoztak érzékelhető javulást az intézmények állapotát, valamint a férőhelyek jellegét és számosságát illetően.

Nem célom a változó elnevezésű operatív programok és konstrukciók elemzése, azonban néhány megállapítást tennék azzal kapcsolatosan, hogy miért nem jelentettek és jelentenek érdemi változást a szakterületre 
érkező milliárdok. A sorban az első és legfontosabb, hogy a konstrukciók teljesen figyelmen kívül hagyták a szakterület állapotát és diszfunkcióit.

A pályázati pénzek alapvetően a hajléktalan emberek azon csoportjára irányultak, akik munkaképes korúak és önellátásra képesek. Ezek elsősorban a munkaerőpiaci aktivitást és az intézményekből való kilépést segítő programok - olyan fontos tevékenységeket jelentenek, amelyek szükségesek ugyan, azonban jellemzőjük, hogy fenntarthatatlanok, nem épülnek be a szabályozásba, a finanszírozásba, hanem a projektek lezárulásával a támogatások, programok, és így a tevékenységek is megszűnnek. Helyi döntéshozókkal folytatott háttérbeszélgetések során elhangzott ugyanakkor, hogy a TÁMOP keretében a 2007-2013-as tervezési időszakban a hajléktalanellátásra tervezett mintegy 8 milliárd forintnak a fele megmaradt és más területekre kellett átcsoportosítani, ugyanakkor sem a férőhelyek bővítése, sem a szükségleteknek megfelelő átalakítása nem történt meg.

A hajléktalan emberek azon csoportjai, akiknek valamilyen tartós bentlakásos intézményben lenne a helye, minden fejlesztésből kimaradtak. Egyfelől az ő elhelyezésük az Unió által nem támogatott cél, hanem nemzeti hatáskörbe tartozó kompetencia, másfelől azonban például a nagy intézmények kitagolására szánt közel 80 milliárd forintos (amúgy ezer sebből vérző) program tervezésénél és megvalósításánál sem számoltak a hajléktalanellátásban vagy az utcán sínylődő pszichiátriai betegekkel és fogyatékossággal élőkkel, bár ez szükséges és megoldható lett volna.

A hajléktalanellátásban dolgozók képzésére is jutott forrás, azonban amennyiben nem profiltiszták az intézmények, akkor a megszerzett tudás sem releváns, nem alkalmazható hatékonyan. A munkakörülmények és a jövedelem javítása nélkül nem mérsékelhető a pályaelhagyás sem.

Általános jelenség, hogy a pályázatok nagy része forráskiegészítést is jelent az abban résztvevő intézményeknek. Vannak azonban olyan konstrukciók, amelyek kizárólag a forráskiegészítést szolgálják, olyan szolgáltatásokat finanszíroznak, amelyek szükségesek ugyan, de az intézmények jogszabályban meghatározott szolgáltatásai között nem szerepelnek, így forrásuk sincsen rá. Ezért az uniós projektek azt a célt szolgálják, hogy a rendszerből hiányzó szolgáltatások forrását biztosítsák.

Példaként említhetem a Rászoruló Személyeket Támogató Operatív Programot, amelynek keretében országosan 4 milliárd forintot költöttünk hajléktalan emberek étkeztetésére. Az étkeztetés biztosításának szükségessége nem feltétlenül egyértelmú, hiszen a rosszabb egészségi vagy mentális állapotú, munkaképtelen, idős, vagy alacsony jövedelmű hajléktalan emberek számára szinte létkérdés lehet, azonban mindenki más számára kifejezetten ellenjavallt, hospitalizáló, deaktivizáló hatású. Az utóbbi csoport tagjai számára is fontos lehetne, például betegség vagy átmeneti jövedelemvesztés esetén, azonban időszakos igénylésre nincsen mód. A program teljes rugalmatlansága a hatékony felhasználást is akadályozza. A program nagyságrendekkel csekélyebb mértékben pszichiáter alkalmankénti elérhetőségét is finanszírozta az intézmények, illetve az ellátott hajléktalan emberek számára. Ez nélkülözhetetlen része kellene legyen jelenleg a szolgáltatási palettának, azonban ez a szolgáltatásbővítés csak addig tart, ameddig az uniós program le nem zárul.

Már-már elrettentő példaként említhetőek a nagy szakmai népszerűségnek örvendő és ismétlődően meghirdetett „Elsőként lakhatás” projektek, amelynek lényege, hogy a hajléktalan embereket közvetlenül az utcáról költöztetik lakásba és részesítik gazdasági-pénzügyi, valamint szociális munkával történő segítségben. A program népszerúsége érthető, hiszen az ügyfeleknek a hajléktalan-ellátásból a lakáspiacra történő bejuttatása sziszifuszi küzdelem, amelyben mind a szociális munkás, mind az ügyfele majdhogynem eszköztelen. Ez a program egyfajta fájdalomdíjként biztosítja a szükséges eszközöket, és így megadja azt az érzést a 
hajléktalan embernek és a szociális munkásnak egyaránt, hogy végre-valahára kiléphetnek a hétköznapok eszköztelenségéből, esélytelenségéből, és olyan tevékenységre fordíthatják közösen az energiáikat, amely az igazi megoldást jelentheti. Valójában sajnos nem rendszerszerúen, csupán a projekt erejéig.

Az igazság azonban az, hogy ez a program az eredeti, egyesült államokbeli, majd Nyugat-Európában átvett formájában fenntartható - köszönhetően az ott meglévő támogatási, lakhatási és egyéb rendszereknek és forrásoknak-, ezzel szemben Magyarországon fenntarthatatlan, ugyanis sem a lakhatási költségek támogatásának, sem az eredményességhez szükséges szociális munkának a költségei nem biztosítottak a program lezárulását követően. Áttekintettem néhány vonatkozó projekt alapadatait, melyek alapján az egy résztvevőre vetített projektköltség 4-5 millió forint.

Az esetlegesen felújított önkormányzati lakások ugyan megmaradnak, de a programba bevont személyek lakhatásának fenntartása a támogatások elmaradásával sajnos egyáltalán nem garantálható, és a résztvevők esetlegesen sikeres integrációja esetén is joggal merül fel a költséghatékonyság kérdése. A programok kiértékelésével foglalkozó dokumentum nem található.

A legnagyobb probléma mégsem ez, hanem hogy Magyarországon - szemben a mintaországokkal - százezreket érint a lakásínség, a lakhatási krízis vagy annak veszélye, és ebben a helyzetben ez a program súlyosan sérti a társadalmi igazságosságot és alkalmas arra, hogy szembefordítson a hajléktalan emberekkel egyes társadalmi csoportokat. Vagyis elmondható, hogy ameddig az intézményrendszer, a jogi szabályozás és a finanszírozás változatlan, addig a projektek eredményei érdemben fenntarthatatlanok és legfeljebb csekély és jellemzően időleges hatással vannak a szolgáltatások minőségére és az ellátórendszer hatékonyságára.

\section{HELYZET-FELTÁRÁS}

A hajléktalan emberek ellátásának intézményrendszere úgy épült ki és kövült meg, hogy soha, semmilyen szükségletfelmérés nem alapozta meg, illetve nem igazolta az intézménytípusok és a szolgáltatások indokoltságát. Ezzel összefüggésben a rendszer céljai is csak igen hézagosan fogalmazódtak meg a jogszabályokban, de még ennek az eszközrendszere sem volt soha biztosított. Ennek megfelelően a rendszer hatékonyságának mérésére sem került sor soha, így a szükséges paradigmaváltás végképpen elmaradt. Ezért kinevezésemet követően elhatároztuk, hogy legalább a magunk területén, azaz a Budapesti Módszertani Szociális Központ és Intézményeiben pótoljuk ezt a hiányosságot.

A munkát az intézményeinkben élők felmérésével kezdtük. A 2017-ben és 2018-ban végzett felméréseinkben megállapítottuk, hogy magas az idős, pszichiátriai beteg, a szenvedélybeteg, valamint az ápolási-gondozási szükségletú betegek aránya.

A feltárt helyzet utóbbiak esetében végképp nyilvánvalóvá tette, hogy az intézményeinkben törvénysértő ellátási gyakorlatot folytatunk, hiszen a Szociális Törvény 84.§-a szerint ugyanis éjjeli menedékhelyen vagy átmeneti szálláson kizárólag önmaga ellátásáról gondoskodni képes ember helyezhető el, míg az önellátásra nem teljesen képes hajléktalan emberek elhelyezésére a hajléktalanok otthona szolgál. Ezt a tényt természetesen jeleztem is a Fenntartónk, a Fővárosi Önkormányzat felé.

A tapasztalatok alapján szélesebb körű fővárosi, valamint teljes körű - a Dél-Dunántúl és az Észak-Alföld régióban történő felmérést kezdeményeztem annak érdekében, hogy a minisztériumot megalapozottan tájékoztathassuk a fővárosi és a vidéki helyzetről - őszintén bízva a változásban. 
A 2018 nyarán végzett felmérés célja az volt, hogy pontosabb képet kapjunk a hajléktalan emberek speciális célcsoportjaiba - úgy, mint pszichiátriai betegek, idősek, rossz egészségi állapotúak, ápolási-gondozási szükségletúek - tartozó emberek számáról, arányáról, esetleges szerhasználatáról, intézményes helyzetéről, illetve az utcán élők intézménybe vonulási hajlandóságáról. Ezek az információk ugyanis markánsan jelzik azokat a valós szükségleteket, amelyek a hajléktalanellátás jelenlegi intézményeiben egyáltalán nem, vagy csak igen korlátozottan elégíthetőek ki.

A felmérés helyszínei Budapest, valamint az Észak-Alföld és a Dél-Dunántúl régió voltak. A két régió kiválasztásának szempontja alapvetően az volt, hogy Budapest mellett képet kaphassunk Pécs helyzetéről is, ahol igen jelentős - Budapest után a második legnagyobb - számú hajléktalan népesség él, továbbá a keleti országrész, Debrecen és Nyíregyháza is bekerüljenek a mintába, amelyek szintén a legrosszabb helyzetű nagyvárosok közé tartoznak ebből a szempontból.

További, gyakorlatias szempont volt, hogy a regionális diszpécserszolgálatot ellátó - így a régióba tartozó intézményekkel rendszeres kapcsolatban álló - szervezetek vezetői problémaérzékeny és nyitott szakemberek, akikhez évtizedes jó kapcsolat füzött, és igen motiváltak voltak, valamint vállalták az önkéntes, helyi szervezőmunkát. Budapest egy ilyen felmérésből kihagyhatatlan, valamint itt közvetlenül elérhető volt a BMSZKI igen nagy számú klientúrája is.

A felmérés eszköze egy elektronikus kérdőív volt. A két régióban személyes találkozókat is szerveztünk az ott múködő intézmények vezetőivel, munkatársaival, amelyeken tájékozódtunk a tapasztalataikról, illetve ismertettük a felmérésünk célját, és mivel mindannyian szívesen vállalták az önkéntes munkával járó adatszolgáltatást, a kérdőívek használatára, felvételére vonatkozó felkészítésüket is elvégeztük.

Az adatbázisba 3528 budapesti és 2300, a két vidéki régióban élő hajléktalan ember adatai kerültek be (lásd a Függelék 1-2. táblázatát). Az adatok feldolgozása SPSS program segítségével történt. Az adatok rögzítését és a táblázatok összeállítását Pataki Zoltán, a BMSZKI munkatársa végezte. Az elsődleges adatokat visszajeleztük a felmérésben résztvevő szervezeteknek, valamint tájékoztattuk a szakminisztériumot, azonban elemzés, tanulmány, publikáció nem készült. A jelen tanulmányban olvasható rövid elemzést kifejezetten erre a célra készítettem.

\section{A kutatás eredményei}

A felmérés 2300 vidéki és 3528 budapesti, azaz összesen 5828 hajléktalan ember adatait tartalmazza. A férfiak és a nők aránya vidéken és Budapesten csekély eltéréssel hasonló, háromnegyed részük férfi, negyedrészük nő. Életkoruk is hasonlóan egyezik, átlagéletkoruk mindösszesen nagyjából 53 év. Ez annyiban is fontos adat, hogy a hajléktalan emberek átlagos életkora folyamatosan emelkedik: 1998-at megelőző években 40 év körül volt az átlagos életkor (Mezei 1998). 2012-ben már 10 évvel magasabb, 50 év volt (Február Harmadika Munkacsoport 2013).

A két vidéki régióban a felmérésbe kerülő emberek több mint 20\%-a él az utcán és Budapesten is közel 20\%-uk, azonban a budapesti felmérésbe csak a nagyobb szervezetek szolgáltattak adatot, így a kisebb - részben főleg, vagy kizárólag utcai munkát végző - szervezetek adatait nem tartalmazza a felmérés. A,Február Harmadika" adatfelvételek ennél magasabb arányban találtak utcán élőket, főleg vidéken. Ennek oka az lehet, hogy az itt tárgyalt felmérés nyáron történt, amikor vidéken több az idénymunka és jellemzően kevesebb hajléktalan ember húzódik be a téli viszonyok között nagyobb védettséget jelentő városokba. 
Fontos adat, hogy a nyugdíjkorhatárt betöltöttek aránya vidéken 19,8\% és Budapesten 23,6\%. A budapesti nyugdíjaskorúak 10,4\%-a utcán, közterületen, 19,1\%-a éjjeli menedékhelyen éjszakázott, míg vidéken ez az arány 16,5\%, illetve 4,5\% volt - vagyis az idős emberek közel 30\%-a, illetve 21\%-a nélkülözte az átmeneti szállások védettebb körülményeit. Az életkori csoportokat tekintve nagyon hasonló adatokat látunk, de kiemelendő, hogy a legnépesebb korcsoport az 56 és 65 év közöttiek csoportja, arányuk Budapesten 35,3\%, a két vidéki régióban $32,7 \%$, rendkívül magas. A hajléktalan emberek populációja egyre idősebb, amire egy korábbi felmérés adatai is rámutatnak: „A korábbi hajléktalan-mérések és az 1999. évi februári mérés szerint is a hajléktalanok többségét (55\%) a 30-49 év közötti középkorosztály teszi ki, ami lényegesen magasabb, mint a magyar társadalom alig egyharmadát (36,5\%) meghaladó azonos korosztálya" (Bényei et al. 2000).

Témánk szempontjából nyomatékosan kiemelendő, hogy az elmúlt évtizedekben folyamatosan és jelentősen nő a hajléktalan emberek átlagos életkora, amely jelentősen változó igényeket és szükségleteket jelent körükben, azonban sem a jogi szabályozás, sem az intézményrendszer, sem az ellátások-szolgáltatások finanszírozása nem reagál minderre.

Budapesten a felmérésben szereplő hajléktalan emberek negyede (864 fö) pszichiátriai beteg volt, a teljes mintából 15\% (528 fő) diagnózissal rendelkező, további 9,5\% (336 fő) pedig a velük kapcsolatban álló szociális munkások megítélése szerinti pszichiátriai beteg volt. A két vidéki régióban még súlyosabb a helyzet, ahol összesen 42,1\% (956 fő) pszichiátriai beteget találtunk, a diagnosztizáltak aránya 20,4\% (463 fő), a vélelmezetteké 21,7\% (493 fő) volt. Budapesten nagyjából négyötödük, a két régióban pedig háromnegyedük volt férfi.

Megvizsgáltuk a pszichiátriai betegek intézményi helyzetét is. A diagnózissal nem rendelkező, de vélelmezhetően pszichiátriai betegeknek Budapesten 54\%-a élt az utcán, közterületen, szállást nyújtó intézményen kívül, a két vidéki régióban is közel 30\%-uk. A diagnózissal rendelkezők körében magasabb volt az átmeneti szálláson élők aránya, különösen Budapesten, ahol ez a többségre jellemző. Ennek magyarázata, hogy a tapasztalatok szerint a diagnózissal rendelkező pszichiátriai betegek körében magasabb a gyógyszerüket szedők aránya, mint a diagnózissal nem rendelkezók között, valamint a budapestieknek nagyobb az esélyük is átmeneti szállásra jutniuk, mivel több a férőhely.

A szerfüggést vizsgálva jelentős különbséget láthatunk Budapest és a két vidéki régió adatai között. Budapesten a nők $71 \%$-a, a férfiaknak pedig 56\% nem függő. Vidéken ezek az arányok sokkal rosszabbak: a nőknek csak 51\%-a, a férfiaknak csak 25\% nem függő. Annyiban hasonló a helyzet, hogy gyógyszerfüggőek inkább a nők (70\%), az alkoholfüggőek inkább a férfiak (85\%). Az illegális szerek használata kizárólag a 35 év alattiakra, míg az alkoholfogyasztás az ennél idősebb korcsoportokban jellemző.

A pszichiátriai betegek szerfüggőségeit vizsgálva azt látjuk, hogy nagy többségük (több mint 80\%-uk) alapvetően gyógyszerfüggő - lévén ez a legkönnyebben és legolcsóbban hozzáférhető drog a számukra. Közel ennyien (64\%-uk Budapesten, illetve 74\%-uk a két vidéki régióban) politoxikománok, azaz többféle tudatmódosító szert is használnak.

A szerhasználattal összefüggésben meg kell említenünk, hogy a hajléktalan emberek ellátásában ezzel a problémakörrel és a vele együtt járó szükségletekkel - minimális kivételtől eltekintve - egyáltalán nem foglalkoznak az intézmények. Addiktológiai munka szinte sehol nem folyik az intézményekben és a sztenderd szociális munkának sem része az ezzel együtt járó következmények ismerete, gyakorlata. Az úgynevezett gondozási tervekben ugyanolyan megállapodások köttetnek (persze, ha egyáltalán) a szerfüggő ügyfelekkel, mint a nem szerfüggókkel, jóllehet nyilvánvaló, hogy esetükben ezek betarthatatlanok, és számukra ez leginkább negatív önbeteljesítő jóslat, vagyis méltatlan, az ügyfelet megbélyegző játszma lehet az eredménye. 
A leglényegesebb szempontrendszer az önellátási képesség kérdése. Erről - a többi kérdéshez hasonlóan - a szociális munkások az ügyfelek ismeretében, a tapasztalataik alapján nyilatkoztak. Újra meg kell említeni, hogy ez azért alapvetően fontos szempont, mert a Szociális Törvény szerint az éjjeli menedékhelyeken és az átmeneti szállásokon kizárólag önmaguk ellátásáról gondoskodni képes embereket lehet elhelyezni.

$A z$ 1. táblázat adatai szerint mind Budapesten, mind a két vizsgált régióban jelentős kisebbségben voltak azok, akiknek nem volt önellátási problémájuk. Budapesten 60,1\%, azaz 2257 ember küzdött önellátási/egészségi problémával, a két régióban pedig az összes felmérésbe került ember 66,2\%-a, vagyis 1523-an. Budapesten némiképpen rosszabb a helyzet, mert kevesebb ugyan az önellátási problémával bíró ember, azonban az állapotuk súlyosabb. Kettő vagy több önellátási problémája volt ugyanis 29,1\%-uknak, 925 embernek. Vidéken ugyanez az arány 19,5\% volt, ami 428 embert jelent.

A pszichiátriai betegek körében is vizsgáltuk az önellátási képesség kérdését. A budapesti pszichiátriai betegek 60\%-ának, a két régióban pedig 65\%-ának volt legalább egyféle egészségügyi, önellátási problémája. Kettő vagy több problémával küzdött az előbbiek közel 30\%-a, az utóbbiak közel 20\%-a.

Nagyon fontos látnunk, hogy melyek is ezek a problémák (melyeket az 1. táblázatban foglaltam össze), hiszen így válik csak érzékletesebbé, hogy milyen nehézségekről van szó, milyen állapotú emberek élnek ilyen szörnyú helyzetben. A legsúlyosabb adat, hogy 438 fő, azaz az összes felmérésbe kerülő ember 7,5\%-a demens beteg. A két vidéki régióban az arányuk kétszerese a fővárosban tapasztalhatónak. Ezek az emberek többnyire képesek lehetnek ugyan önmaguk ellátására, azonban fokozott figyelmet, törődést igényel az állapotuk, hiszen térben és időben nem tudnak tájékozódni, elkóborolhatnak, eltévedhetnek. Vásárláskor, orvoshoz menéskor, ügyeik intézésénél kísérni kell őket.

1. táblázat. A hajléktalan-ellátásba került emberek fö jellemzői önellátási problématípusok szerint

\begin{tabular}{|l|c|c|c|c|}
\hline \multirow{2}{*}{ problématípus* } & \multicolumn{2}{|c|}{ Budapest } & \multicolumn{2}{c|}{ Vidék } \\
\cline { 2 - 5 } & fó & $\%$ & \multicolumn{2}{c|}{ fö } \\
\hline rendszeresen szed gyógyszert segítséggel & 229 & 6,7 & 194 & 8,5 \\
\hline táplálkozáshoz segítségre szorul & 29 & 0,9 & 30 & 1,3 \\
\hline széklet-, vizeletürítéshez segítségre szorul & 83 & 2,5 & 75 & 3,3 \\
\hline tisztálkodáshoz segítségre szorul & 108 & 3,2 & 109 & 4,8 \\
\hline mozgáshoz/helyváltoztatáshoz segítségre szorul & 269 & 8,0 & 192 & 8,5 \\
\hline mozgáskorlátozott & 301 & 8,9 & 218 & 9,6 \\
\hline demens & 190 & 5,4 & 248 & 10,9 \\
\hline krónikus beteg & 2005 & 57,9 & 1402 & 63,4 \\
\hline sem betegsége, sem mentális állapota nem korlátozza & 1271 & 39,9 & 777 & 35,4 \\
\hline
\end{tabular}

*A probléma típusánál az önellátást leginkább akadályozó állapotot tüntettük fel.

A felmérés vizsgálta azt, hogy milyen intézményi környezetben vagy éppen intézményen kívül élnek-e ezek az emberek. Talán a legszembetűnőbb adat, hogy az utcán, közterületen élő emberek többsége is önellátási, egészségügyi problémával küzd. Arányuk Budapesten 53,6\%, míg vidéken 62,5\%. Ez utóbbi adat azt is jelenti, hogy (eltekintve a hajléktalanok otthonában élő néhány embertől) a két vidéki régióban a legrosszabb állapotú emberek az utcán élnek, nem intézményben. Mondhatnánk keserűen, hogy az ő helyzetük legalább nem ütközik törvénybe, szemben az intézményben, hasonló problémákkal élő emberek helyzetével.

Hasonló, közel kétharmados arányban találhatunk önellátási, egészségügyi problémával küzdő embereket a budapesti átmeneti szállásokon, míg az éjjeli menedékhelyeken is hasonló állapotú emberek éjszakáznak, az egészségeseknél jócskán nagyobb, 60\%-ot meghaladó arányban. 
Magyarázatra szorul, hogy a legkevésbé rossz adatokkal a budapesti rehabilitációs szállón élő emberek rendelkeztek. Ennek az az oka, hogy ebben az intézményben alkoholrehabilitáció folyik, amelyben munkaképes korú és állapotú emberek vesznek részt. Az utcán élők körében a pszichiátriai betegek aránya hasonló: Budapesten $36,2 \%$, a két régióban némileg magasabb, 42\% volt. A diagnózissal nem rendelkezők aránya mintegy kétháromszorosa volt a diagnózissal rendelkezőkének, vagyis a többség vélhetően egyfajta városi vademberként soha nem került kapcsolatba a pszichiátriai szakellátással, gyógyszert sem szed, és kezelés nélkül az esélye is minimális bármi fajta boldogulásra.

Az utcán élők között a két régióban és Budapesten közel egyformán magas volt a függőséggel élők aránya, 80-83\%, ami túlnyomó részben alkoholfüggőséget jelent. Az utcán élők között Budapesten 53,6\%, a két régióban pedig 62,5\% volt az egészségügyi, önellátási problémával küzdők aránya. Közülük Budapesten közel 25\%, a két régióban $27 \%$ volt a kettő vagy több önellátási/egészségügyi problémával küzdő, utcán élő hajléktalan emberek aránya.

Végezetül megvizsgáltuk azt a kérdést, hogy az utcán élő hajléktalan emberek hány százaléka gondozható intézményben a szociális munkások tapasztalata szerint. Budapesten az utcán élők közel 80\%-a, a két régióban pedig több mint fele biztosan vagy esetlegesen vállalná az intézménybe kerülést. Ez nagyon fontos adat arra nézve, hogy még a szükségleteknek nem vagy csak igen korlátozottan megfelelő intézmények, illetve férőhelyek is vonzóak lennének - ha lennének egyáltalán...

Ez a felmérés is igazolta, hogy főleg a két vidéki régióban továbbra is perverz elhelyezési gyakorlatot folytat az intézményrendszer: azaz a legjobb fizikai és mentális állapotú és anyagi helyzetű emberek élnek a legkomfortosabb intézményi környezetben, az átmeneti szállókon, míg a legrosszabb egészségi és mentális állapotú emberek a legrosszabb körülmények között - az éjjeli menedékhelyeken és az utcákon. Ez a jelenség nyilván összefügg egyrészt azzal, hogy a jobb állapotú és helyzetű emberek érdekérvényesítő képessége is erőteljesebb, másrészt azonban arról is szó van, hogy az intézmények is ezeknek az együttmúködésre képesebb, kevesebb problémát jelentő emberek felvételében érdekeltek.

Budapesten enyhült ez a diszfunkció, elsősorban azért, mert az átmeneti szállások növekvő mértékben adnak helyet az ápolási-gondozási szükséglettel vagy mentális problémákkal küzdő hajléktalan embereknek. Sajnos ez is diszfunkció, bár más természetű. A kívánatos természetesen az lenne, ha mindenki elhelyezéshez jutna és az állapotának és a szükségleteinek megfelelő elhelyezést kapna, azonban az ennek megállapítására vonatkozó eljárások és gyakorlatok is hiányoznak a mai rendszerből, akárcsak az erre a célra szolgáló intézmények.

A felmérés eredményeiről természetesen szóban és írásban egyaránt tájékoztattuk az illetékeseket...

Ekkor pedig már ismert volt az Alapvető Jogok Biztosának Jelentése is, az AJB-285/2015. számú ügyben:

„A szociális igazgatásról és szociális ellátásokról szóló 1993. évi III. törvény szociális szolgáltatásokat nevesitő katalógusa a hajléktalanok által igénybe vehető alapszolgáltatások között étkeztetést, utcai szociális munkát és nappali ellátást nevez meg, szakositott ellátási formaként pedig a rehabilitációs intézmények, éjjeli menedékhelyek és átmenetei szállásokállnak a rendelkezésükre. Az intézménytípusokat a jogszabályok egzakt módon, de rendkivül szükszavúan határozzák meg az alkalmazhatóság szempontjából kifejezetten merev helyzetet teremtve. Mindezek alapján álláspontom szerint pontosabban kidolgozott, illetve részletezöbb kompetencia-meghatározásokkal kell megteremteni az összhangot a komplex problémákkal (kumulálódó betegségekkel, halmozott hátrányokkal) jelentkező ügyfélkör 
speciális igényei és az elfogadható szakmai színvonalú ellátás biztositásának szükségessége között. Erre is figyelemmel a jelentés tényállásában foglalt válaszok és adatok nyomán megállapítom, hogy az egyes ellátás-típusok müködtetésének jogszabályi és finanszírozási környezetében tapasztalható hiányosságok, bizonytalanságok (pl. a pszichiátriai, addiktológiai ellátás tekintetében) továbbra is a jogbiztonság követelményével összefüggő alapjogi visszásságot idéznek elő és tartanak fenn. Rá kell mutatnom ezzel összefüggésben, hogy e bizonytalanságok következtében a szociális segitő szakma eszközei számos esetben hatástalanokká váltak: a fedél nélküliek utcai, közterületi jelenlétének problémaköre a rendészeti megoldásokkal és a társadalmi szolidaritás csökkenésével párhuzamosan a hajléktalan emberek, valamint az utcai lét jelenségével együtt élö „többség” közötti konfliktushelyzetekhez vezethetnek, ami súlyos problémákat, egyre nehezebben megoldható helyzetet eredményezhet" (AJB-285/2015).

A hajléktalan emberek ellátásával foglalkozó intézményrendszer súlyos diszfunkcióit sajnos terjedelmi okokból nem tudom bemutatni. Egyetlen fontos következményét azonban ki kell emelni; az a tény, hogy az intézmények nem biztosítják a szükségleteknek megfelelő szolgáltatásokat, döntő mértékben összefügg az utcán élők magas számával is, hiszen ez a körülmény egyaránt jelentősen csökkenti az intézmények bevonzó képességét és megtartóerejét.

\section{Esélytelenül?}

Az utca emberéhez hasonlóan a szakemberek figyelme is alapvetően az intézményen kívül rekedtek felé fordult, az intézmények falai közé bejutó emberek helyzete iránt mindenki elvesztette az érdeklődését. Úgy tekintettek rájuk, mint akik már kvázi biztonságban vannak. Ez a szemlélet az első években még érthető volt, hiszen az intézmények a kríziskezelés fázisában alakultak és múködtek. Beszédes körülmény, hogy a rendszerváltást követő időszakban a hajléktalan emberek ellátásának kiépítését, koordinálását a Népjóléti Minisztériumon belül az úgynevezett Szociális Válságkezelő Program Iroda irányította.

A Szociális Törvény elfogadását követően, 1993-tól a kezdeti mintára épült tovább a rendszer, de továbbra is a kríziskezelés lázában. Ennek következtében - a politikusoktól a hivatalnokokig, az intézményvezetőkig és a szociális munkásokig - minden szereplő számára ez az értékrend, ez a viszonyulás, és ez a kvázi-eszközrendszer vált természetessé. Az idők során a nagyobb befolyásért és a több pályázati-fejlesztési bevételért folyó, szervezetek közötti pozícióharc már egyre kevésbé a hajléktalan emberek biztonságáért, hanem egyre inkább a szervezetek érdekei mentén, valamint a vezetőik egzisztenciális biztonsága, a megszerzett pozíciók védelme és további erősítése érdekében zajlott.

Ebben a helyzetben szóba sem jöhettek a hajléktalan emberek szélsőséges mértékben eltérő állapotának és szükségleteinek megfelelő változások az intézményrendszerben, hiszen minden változás a kialakult és megszokott pozíciók biztonságát fenyegette volna. Személyes szinten ugyanakkor az egyes szociális munkások minden szervezetben átélték a rászorulók ellátásának morális felelősségét, és feltételek híján is mindent elkövettek, hogy megfeleljenek ennek a felelősségnek.

Jelenleg a hajléktalan emberek ellátásának rendszere egy olyan kórházhoz hasonlatos, amely mindössze egy ütött-kopott, elavult műszerezettségű sürgősségi részlegből áll, de nincsen sem belgyógyászat, sem kardiológia, semmilyen más osztály. Így aztán annak sincs semmi jelentősége, hogy nincsenek ellátási protokollok és nincsen triázs, hogy csupán esetlegesek és hevenyészettek a diagnózisok, hiszen sem a kivizsgálásra, sem a gyógyításra nincsen valójában lehetőség. 
A sajtóban gyakori ugyan a hivatkozás a számos üres férőhelyre, ezek azonban a kizárólag éjszaka nyitva tartó éjjeli menedékhelyeken találhatóak, amelyek teljesen alkalmatlanok az idősek, az ápolási/gondozási szükségletű vagy a pszichiátriai betegek, a fogyatékkal élők ellátására. A kialakult helyzetért pedig természetesen a hajléktalan emberek a felelősek, mert nem akarják igénybe venni a szabad férőhelyeket...

A hajléktalanság felszámolásának perspektívája címú tanulmány (CERA TRONCO Kft. 2013), ami 2021 áprilisában még a Parlament honlapján is elérhető volt, sötét képet fest a szakterület szervezeteiról és helyzetéről. Megállapítja, hogy a megoldás irányából a kezelés irányába fordult a hajléktalansághoz való viszony: kiépült az az ellátórendszer a maga visszásságaival, a szinten tartásra alapozott elveivel, megkövesedett, kontraproduktív struktúrájával, amelyet zárt vezetői kör és monopolizált szakterület jellemez.

Tény, hogy a hajléktalan szakmában megállt az ido”, a „piac” régóta felosztva. Ugyanazok a szervezetek és ugyanazok a vezetők a szakterület meghatározó szereplői az elmúlt 20-25 évben. Az elmúlt években a belső erőviszonyok ugyan jelentősen megváltoztak, de a szövetség hatékony és szoros maradt, gyakorlatilag uralja a szakterületet. Döntenek a pluszforrások elosztásáról, a kommunikációról, az inkább csak hangzatos, alkalmankénti akciókról és minden felmerülő kérdésről, helyzetről. Nincs konfliktus, nincs kibeszélés, a kialakított rendszer egyensúlya, stabilitása, változatlansága közös érdek. Egyes tagjaik keze mindkét fő politikai táborban nagyon messze elér. A körön kívüliek igazodnak a játékszabályokhoz, elfogadják, ami jut, és nem kalózkodnak pápai vizeken. Ha fel is tűnnek néha új szereplők, nem lehetnek a kánon tagjai. Azaz: zár a rendszer, nincs befogadás, nem fogad be senkit, aki megzavarhatja a kialakult erőviszonyokat.

Az ország férőhelyeinek negyedrészét biztosító intézmény új vezetőjeként, magam sem nyertem befogadást. Régi baráti szövetségesem, ma már rendkívül befolyásos személy, nyíltan megmondta, hogy nem támogatja a céljaimat. Akkor még nem gondoltam, hogy ez ilyen egyszerúen múködik...

Nem vonatkoztathatunk el attól a körülménytől sem, hogy 10 éve már mind fővárosi, mind országos szinten a szakterület képviselői osztják el - utóbbi esetében az ágazati irányítás képviselőinek részvétele mellett - a szervezetek között pályázat útján azt az évi több mint 600 millió forintot, amelyet a Fővárosi Önkormányzat és a szakminisztérium a normatíva fölött a hajléktalanellátás céljaira biztosít. Fontos ugyanakkor leszögezni, hogy olyan - többnyire azonos és ismétlődő - feladatok finanszírozása történik ily módon, amelyek kulcsfontosságúak, és az ellátás, valamint a finanszírozás integráns részei kellene legyenek. Zömmel beépíthetőek lennének tehát a jogi szabályozásba és a finanszírozásba egyaránt, illetve akár más rendszerben is eloszthatóak lennének.

Politikai és szakmai döntéshozókkal folytatott háttérbeszélgetéseim során elhangzott, hogy milyen könnyú és hatékony volt bármilyen egyeztetés a hajléktalan szakterület képviselőivel, bezzeg más, „rosszul szervezett" szakmákkal mennyi baj és probléma volt a legkisebb ügyekben is. Partnereim több alkalmat is említettek, amikor egy-egy döntési helyzet kapcsán az éppen soros államtitkárok szájából is elhangzott, hogy „jaj, ne, várjál, ezt még meg kell beszélnem X-szel vagy Y-nal." Egyszer egy helyettes államtitkár azt mondta nekem hatszemközt, hogy: „figyelj, értem, amit mondasz, értem a problémát, de én ezzel nem mernék elöhozakodni egy kormányülésen."

A rendszer tehát attól igazán múködőképes és örökkévaló, hogy a mindenkori politika ingerküszöbét nemigen éri el és megfelel az ágazati irányítás érdekeinek is. Utóbbi hivatalnokok ugyanis többnyire pontosan látják a súlyos diszfunkciókat, de nem érzik magukat elég erősnek a konfliktusokhoz, és az érdekeik is azt kívánják, hogy „béke és nyugalom” honoljon a szakterületen. A béke és nyugalom számukra a szervezetek elégedettségét, hallgatását jelenti, nem pedig a rászorulók elégedettségét és állapotuknak, szükségleteiknek 
megfelelő, megnyugtató ellátását. A hivatalos vélemény szerint tehát „Magyarországon Európa egyik legjobban szervezett hajléktalanellátása müködik." ${ }^{\prime 3}$

A változások elmaradásának azonban akár még hosszú évekre szólóan súlyos következménye volt. Az Európai Unió költségvetéséből érkező milliárdok és a Főváros által évente biztosított plusz százmilliók, valamint a „hajléktalan kórház” 2011-ben való létrehozása dacára az utca képe nem változott, hiszen ehhez a hajléktalan emberek mentális és egészségi állapotának, szükségleteinek megfelelő intézményekre, szolgáltatásokra és kapacitásokra lenne szükség - enélkül az intézmények megtartóereje is csekély. A belvárosi fejlesztések és a megújuló történelmi helyszínek látványát, élményét is erősen zavarta a változatlan utcakép, így ez a tény egy nagyobb szabású átadási ceremóniát követő kormányülésen is téma volt. A másnapi miniszteri értekezlet ugyan zaklatott hangulatban telt, de minden maradt a régiben. A politika ekkor veszthette el végképpen a szakma iránti bizalmát és tanácstalanul, egyéb eszköze nem maradván, egyre inkább a kényszerítő erőben vélte megtalálni a megoldást, amelyet végül törvénybe is iktatott. A helyzet és az utca képe azonban azóta is változatlan.

Jelenleg nincsen tehát sem a politikában, sem a szakterületen olyan dinamikus szereplő, akitől változás lenne várható és ez a helyzet várhatóan még sokáig így marad. A politika számára a hajléktalan emberek helyzete legfeljebb addig szempont, ameddig szem előtt vannak az utcákon, azonban az erdő mélyén, a fúthetetlen sufnikban, a házak pincéiben meghúzódva vagy akár az intézmények falain belül már semmiképpen. A befolyásos szervezetek vezetői pedig szintén nem érdekeltek a változásban, és így - bár az erőviszonyok jelentősen eltolódtak az utóbbi években a szövetségen belül - a szövetségük is bizonyosan tovább él... hacsak a politika egyszer, valamiért másképpen nem dönt - de félő, hogy messze még ez a pillanat. Ehhez ugyanis egy befogadóbb társadalomra, támogató közvéleményre és szolidáris közakaratra - vagyis talán csodára lenne szükség.

A társadalmi gondoskodás a mindenkori emberi társadalmak kulcskérdése, morális állapotának, fejlettségének fokmérője. Mértékének, mibenlétének, változásainak mentén leírható az emberi társadalom fejlődésének története.

Itt tartunk jelenleg.

3 Forrás: https://www.echotv.hu/hirek/2018/10/02/oktober-15-tol-meghosszabbitjak-a-nappali-melegedok-nyitvatartasat. (Letöltve: 2021.10.10). 


\section{HIVATKOZÁSOK}

1949. évi XX. törvény A Magyar Köztársaság Alkotmánya

1993. évi III. törvény a szociális igazgatásról és a szociális ellátásokról

Az alapvető jogok biztosának Jelentése az AJB-285/2015. számú ügyben Elérhető: https://www.ajbh.hu/documents/10180/1957691/ Jelent\%C3\%A9s+a+t\%C3\%A9li+haj|\%C3\%A9ktalan-ell\%C3\%A1t\%C3\%A1sr\%C3\%B3l+285_2015/1205bd6b-aa0c-4242-bc30e863126f2785?version=1.0 [Letöltve: 2021-11-14].

Az állampolgári jogok országgyúlési biztosának Jelentése az AJB-3240/2011. számú ügyben.Elérhető: https://ajbh.hu [Letöltve: 202111-14].

Bényei Z. - Gurály Z. - Győri P. - Mezei Gy (2000) Tíz év után. Gyorsjelentés a fóvárosi hajléktalanokról - 1999. Esély, 12(1), 62-95.

CERA TRONCO Kft. (2013) A hajléktalanság felszámolásának perspektívája Elérhető: https://docplayer.hu/amp/3392451-Ahajlektalansag-felszamolasanak-perspektivaja.html [Letöltve: 2021-11-14].

Czibere K. - Mester D. (2020) A magyar szociális szolgáltatások és főbb jellemzőik 1993-2018 között In Kolosi T. - Szelényi I. - Tóth I. Gy. (szerk.) Társadalmi Riport 2020. Budapest: TÁRKI, 434-449.

„Február harmadika” Munkacsoport (2013) Február harmadika adatfelvétel. Elérhető: https://februarharmadika.blog.hu/tags/2013 [Letöltve: 2021-10-11].

„Február harmadika” Munkacsoport (2018) Gyorsjelentés a 2018. februári hajléktalan adatfelvételről. Elérhető: https:// februarharmadika.blog.hu/2018/03/29/negy_hajlektalan_kozul_harom_lakasban_elhetne_181 [Letöltve: 2021-11-14].

Gyarmati A. (2019) Idősödés, idősellátás Magyarországon. Helyzetkép és problémák. Budapest: Friedrich-Ebert-Stiftung. Elérhető: https://library.fes.de/pdf-files/bueros/budapest/15410.pdf [Letöltve: 2021-10-11].

Gyuris T. (2002) Hajléktalanság 2001-2002. Kutatási beszámoló. Kapocs, 1, 16-29.

Gyuris T. - Ladányi E. - Forrai E. (szerk.) (2005) A szociális szolgáltatások helyzete Magyarországon 2001-2005. Budapest: Nemzeti Család- és Szociálpolitikai Intézet.

Hányan kapnak mennyi nyugdíjat? (2019) NyugdíjGuru News (nyugdijguru.hu), szeptember 19. Elérhető: https://www.nyugdijguru.hu/ nyugdij/oregsegi-nyugdij/hanyan-kapnak-mennyi-nyugdijat [Letöltve: 2021-11-14].

Kiss B. (2016) A szociális biztonság alkotmányjogi megítélése Magyarországon a rendszerváltozást követően. In Homoki-Nagy M. - Hajdú J. (szerk.) Ünnepi kötet Dr. Czúcz Ottó egyetemi tanár 70. születésnapjára. Szeged: SZTE Egyetemi Kiadványok, 357-362.

KSH STADAT (2019) 2.5.21. Nyugdíjak, ellátások, járadékok és egyéb járandóságok, sajátjogú nyugdíjak. Elérhető: https://www.ksh.hu/ docs/hun/xstadat/xstadat_eves/i_fsp001.html 2.5.21. [Letöltve: 2021-11-14].

KSH STADAT (2021) 25.1.1.35. Saját jogon járó nyugdíjban és ellátásban részesülők a teljes ellátás összege szerint, január. Elérhető: https://www.ksh.hu/stadat_files/szo/hu/szo0035.html [Letöltve: 2021-11-14].

Magyarország Alaptörvénye (2011. április 25.)

Mezei Gy. (1998) Vendégségben a polgári világban. Hajszolt Hírlap, május-július 6-13.

Rácz Z. (2016) A szociális biztonsághoz való jog Magyarországon a rendszerváltás óta eltelt időszakban. In Homoki-Nagy M. - Hajdú J. (szerk.) Ünnepi kötet Dr. Czúcz Ottó egyetemi tanár 70. születésnapjára. Szeged: SZTE Egyetemi Kiadványok, 535-542.

Szalai A. (2019) Utolsó zugok. Magyar Narancs, március 17. Elérhető: https://magyarnarancs.hu/belpol/utolso-zugok-116725 [Letöltve: 2021-11-14].

Szociális ellátás elhelyezéssel (2019) In Szociális Statisztikai Évkönyv, 2019. Budapest: Központi Statisztikai Hivatal, 155-176.

Várakozók Jelentése 2016, 2019. Elérhető: https://szocialisportal.hu/wp-content/uploads/2016/08/varakozok_2016_junius.pdf [Letöltve: 2021-11-14]. 
FÜGGELÉK

\section{1. táblázat}

\begin{tabular}{|l|c|}
\hline $\begin{array}{l}\text { A felmérésben részt vevő budapesti } \\
\text { szervezetek }\end{array}$ & $\begin{array}{c}\text { A megkérdezett hajléktalan } \\
\text { emberek száma }\end{array}$ \\
\hline Baptista Szeretetszolgálat & 582 \\
\hline BMSZKI & 1732 \\
\hline Hajléktalanokért Közalapítvány & 282 \\
\hline Léthatáron Alapítvány & 46 \\
\hline Magyar Máltai Szeretetszolgálat & 435 \\
\hline Magyar Vöröskereszt & 339 \\
\hline Twist Olivér Alapítvány & 112 \\
\hline Összesen & 3528 \\
\hline
\end{tabular}

\section{2. táblázat}

\begin{tabular}{|l|r|}
\hline $\begin{array}{l}\text { A felmérésben részt vevő vidéki településeken } \\
\text { megkérdezett hajléktalan emberek száma }\end{array}$ & \\
\hline Debrecen & 397 \\
\hline Fehérgyarmat & 15 \\
\hline Hajdúhadház & 47 \\
\hline Kaposvár & 119 \\
\hline Kisvárda & 22 \\
\hline Nagykálló & 20 \\
\hline Nyíregyháza & 239 \\
\hline Pécs & 1362 \\
\hline Szeged & 65 \\
\hline Szigetvár & 14 \\
\hline Összesen & 2300 \\
\hline
\end{tabular}

